\title{
EFFECT OF BIOFUEL ON PERFORMANCE AND EMISSIONS OF DIESEL ENGINE
}

\author{
Tomas Mickevicius, Stasys Slavinskas \\ Vytautas Magnus University, Lithuania \\ tomas.mickevicius1@vdu.lt, stasys.slavinskas@vdu.lt
}

\begin{abstract}
The paper presents a comparative analysis of the diesel engine performance and emission characteristics, when operating on diesel fuel (D) rapeseed methyl ester (B) and rapeseed methyl ester -butanol BBu20 blend, at various loads and 2000 rpm engine speeds. The experimental tests were performed at a four-stroke, single-cylinder, air-cooled diesel engine FL511. The bench test results showed that the brake specific fuel consumption increased, when operating on biodiesel-butanol fuel blends compared to neat diesel fuel. The maximum brake thermal efficiency sustained at $4.7 \%$ lower in comparison with diesel fuel operating at full engine load. When the engine was running at maximum torque mode using biodiesel-butanol fuel blend $\mathrm{BBu} 20$, the total emissions of nitrogen oxides decreased. Thus, the greatest fossil fuel challenge related with the simultaneous reduction of both the NOx emissions and the smoke opacity (PM) could be reasonably solved by switching a diesel engine on totally renewable biodiesel-n-butanol biofuel blend.
\end{abstract}

Keywords: diesel engine, biofuel, engine efficiency, emissions, smoke opacity.

\section{Introduction}

The transport sector was affected by the global pandemic crisis. Global road transport activity was almost 50\% below the 2019 average by the end of March 2020. For the energy sector, this trend has had huge knock-on effects for oil consumption, contributing to a $\%$ decrease in demand in the first quarter of 2020. The passenger transport, which is responsible for almost $40 \%$ of final oil demand and $15 \%$ of global energy-related carbon emissions, any crisis-induced changes to way we travel will have significant global implications, if changes to transport behaviours become permanent after lockdowns are lifted. Therefore, a main question for the energy sector is whether changes to transport behaviours during the crisis may result in a permanent change in behaviour, as well as transport energy use, or if transport patterns will revert to work as usual, when the crisis ends. Research has shown that disruptions can be a catalyst for shifts towards more sustainable transport behaviours, but avoiding a return to precrisis behaviours requires governments to take decisive actions. However, the consumption of a fossilorigin fuel creates the urgent environment pollution problems and climate change. The Directive of the European Parliament and of the Council on the promotion of the use of energy from renewable sources has confirmed the objective that energy consumption in Europe should be $20 \%$ with renewable fuels [1]. This Directive sets at least $10 \%$ of renewable fuel consumption in the transport sector and poses a challenge to both researchers and industry. The researchers are working on that, this Directive becomes implemented.

Use of renewables, oxygenated and sulfur-free fuels for internal combustion engines or blends with conventional diesel save fossil fuel energy resources and do less damage to the environment. 1-butanol, also known as n-butanol, has a straight chain structure with the hydroxyl group at the rear of the carbon and it is very widely used in the industrial sector. Butanol is pointed out as an alternative biofuel due to various advantages. Progress in butanol production has been recently introduced to improve genetic modification butanol-producing strains and fermentation technology butanol [2]. Normal butanol $\left(\mathrm{CH}_{3} \mathrm{CH}_{2} \mathrm{CH}_{2} \mathrm{CH}_{2} \mathrm{OH}\right)$ with a molecular weight of $74.12 \mathrm{~g} \cdot \mathrm{mol}^{-1}$ is a colourless liquid of alcoholic origin of medium volatility. It is sufficiently flammable with a flash point of about $35^{\circ} \mathrm{C}$, it contains $21.62 \%$ by weight of fuel bound oxygen with a boiling point of about $117.40^{\circ} \mathrm{C}$ at $760 \mathrm{~mm} \mathrm{Hg}$. This renewable biofuel added to the widely known rapeseed oil methyl ester (RME) reduces the density, viscosity, atomic $\mathrm{C} / \mathrm{h}$ ratio and provides a large amount of fuel bound oxygen, which with its good properties of evaporation improves the mixing speed of air and fuel vapours and combustion of biofuel mixtures. As biodiesel and n-butanol contain fewer carbon atoms in the molecules than traditional diesel fuel, improved combustion has the advantage of reducing the total amount of $\mathrm{CO}_{2}$ and $\mathrm{CO}$ emissions below the respective values pure biodiesel or pure diesel could be expected. When used as an oxygenator source in previous tests, anhydrous ethanol $\left(\mathrm{CH}_{3} \mathrm{CH}_{2} \mathrm{OH}-99.9 \%\right.$ by volume) generated more concern for researchers than n-butanol in terms of consistency of the mixtures, extension of the auto-ignition delay and combustion peculiarities. However, the presence of a lighter n-butanol in biodiesel also reduces the mixed cetane number, the net calorific value, and therefore affects the mass of biofuel 
consumed per unit of efficient energy or power developed by the engine. A sensitive interaction between the advantageous and disadvantageous operating properties of renewable energies of very different nature, origin and production technology from those of biodiesel and n-butanol can lead to ambiguous development trends in combustion attributes, net heat release rate and engine emissions [3]. Unlike ethanol, the operating properties of n-butanol are much more similar to those of pure diesel or biodiesel, except for a lower density and viscosity and about twice as much lower cetane number [4].

In addition, n-butanol offers operational advantages, as its judicious addition to biodiesel can significantly reduce the production of $\mathrm{CO}$ and smoke (PM) due to the significantly lower atomic $\mathrm{C} / \mathrm{h}$ ratio and the high mass of oxygen bound fuel (wt, \%) content. Next, the lower density and viscosity of n-butanol may have a positive impact on biofuel injection, atomisation and vaporisation characteristics, the air and fuel vapour mixing rate in the hot in-cylinder compressed air charge, combustion attributes and thus the engine out emissions when operating under steady and transient conditions [5].

The researchers conducted a broad-spectrum chemical-analytical study of the properties of butanol, hydrogenated vegetable oil, and diesel fuel blends and measured nearly 20 chemical and physical parameters, particularly such as the flash point, cetane number, viscosity and the cold filter clogging point (CFPP) to find out whether the three-component mixtures are suitable for compression-ignition engines. The scientists calculated that the viscosity decreases in the test range almost by the insert, and every $1 \%$ by weight of the butanol (w/w\%) added to the mixture causes a weak viscosity-reducing effect of $1.4 \%$. They also noted that the addition of butanol reduced the flash point of the mixture to around $40{ }^{\circ} \mathrm{C}$, which is in line with the minimum standard DIN EN ISO 2719, revised in 2016 [6]. This reduction is very important for transport fire safety and logistics security. As blends of butanol-diesel and/or nbutanol-biodiesel fuels are flammable, protective equipment must be used as in the petrol supply chain. In an extensive experimental study, the authors revealed that there is a relationship between linear elements and an increase of $1 \%$ in butanol in hydrotreated vegetable oil (HVO), it decreases the average $\mathrm{CN}$ rating by 0.4 points [6].

The researchers found that an increase in the alcohol content of diesel or biodiesel increased the auto-ignition time. This increase was not linear, but more abrupt, when high in alcohol, and was greater with ethanol than with butanol. For butanol blends, the lag times were very similar, when diesel or biodiesel were used [7]. Studies have shown that due to the longer auto -ignition delay period of the diesel-n-butanol test portion, the mixture of combustion angle-reflecting fuel and energy conversion efficiency is MBF 50 (mass burn fractions), in which half of the injected fuel portion burns and the end of combustion occurs earlier in the engine cycle after the top dead centre (TDC). As a result, the thermal efficiency of the brakes increases to a maximum of 0.383 , when working with a diesel fuel mixture containing n-butanol DB3 (3.0\% by mass oxygen) at $1800 \mathrm{rpm}$ speed. Although NOx, CO and THC emissions are reduced by $5.1 \%, 29.5 \%$ and 3.7 times, respectively, when working with n-butanol, using a DB4 mixture ( $4.0 \%$ by mass of oxygen) compared to values similar to diesel at full speed at $2500 \mathrm{rpm}$. [3]. The authors have made further progress with the introduction of fully renewable and environmentally friendly binary biodiesel-n-butanol biofuels to increase combustion and significantly reduce $\mathrm{CO}$ and particulate matter (PM) emissions from compression ignition engines, biofuels made from biodiesel and n-butanol [8].

The authors investigated and compared the effects of biodiesel-ethanol (BE) and biodiesel-nbutanol $(\mathrm{BBu})$ blends on the combustion, performance and exhaust emissions of a direct injection diesel engine. The experiments were performed using direct blends of diesel, biodiesel and BE5 (5\% ethanol and $95 \%$ biodiesel, v/v), BE10, BE15 and BBu5, BBu10, BBu15 biofuels using five engine loads and constant $1800 \mathrm{rpm}$. Blended fuels result in higher maximum heat release rates, higher maximum cylinder pressures, longer auto-ignition delays and shorter combustion times, which have had a negative impact on the combustion noise and stability in the plant, especially when driving with BE blends [9]. In addition, on average, mixtures of $\mathrm{BBu}$ and $\mathrm{BE}$ out of five engine loads increased $\mathrm{CO}$ emissions by $13.7 \%$ and $22.8 \%$, respectively, and $\mathrm{HC}$ emissions by $5.6 \%$ and $29.2 \%$, respectively; however, NOx emissions decreased by $6.5 \%$ and $28.0 \%$, particulate mass concentrations by $20.7 \%$ and $20.6 \%$, and particle number concentrations by $22 \%$ and $21 \%$, respectively. Thus, BE blends have been shown to be more effective in reducing the particulate matter and NOx emissions, while BBu blends show lower $\mathrm{CO}$ and $\mathrm{HC}$ emissions [9]. 
In spite of numerous studies, which have focused on renewable biofuel using on diesel engines, it is not entirely clear what could be a rational blending rate of renewable biodiesel and n-butanol. The question, what proportion of renewable biodiesel and n-butanol mix could be acceptable for dieselpowered machines and electric generators, is not answered yet. In this study, researchers intend to focus on the changing trends in diesel engine performance, biofuel energy conversion efficiency and exhaust emissions from alternating neat biodiesel derived from rapeseed oil fuel and fully renewable binary nbutanol blend. The aim of the study is to investigate the impact on engine performance and emission characteristics of the diesel engine operating on commercial diesel fuel as a baseline fuel, biodiesel fuel, and biodiesel-n-butanol blend.

\section{Materials and methods}

The experimental examinations are performed in the engine-test laboratory at Power and Transport Machinery Engineering Institute of the Vytautas Magnus University - Agricultural Academy. The technical characteristics in more details are listed in Table 1. Load characteristics of the engine were taken when operating at $0.07 \mathrm{MPa}(10 \%), 0.30 \mathrm{MPa}(50 \%)$ and $0.52 \mathrm{MPa}(100 \%)$ loads and constant engine speed of $2000 \mathrm{rpm}$, at which an engine maximum torque develops.

Table 1

\section{Engine FL 511 specifications}

\begin{tabular}{|l|l|}
\hline Type & Deutz FL 511 \\
\hline Number of strokes & 4 strokes \\
\hline Number of cylinders & Single-cylinder \\
\hline Bore, $\mathrm{mm}$ & 100 \\
\hline Stroke, $\mathrm{mm}$ & 105 \\
\hline Displacement volume, $\mathrm{cm}^{3}$ & 825 \\
\hline Compression ratio & 17 \\
\hline Injection timing advance in crank angle degree (CADs) before TDC & $24^{\circ}$ \\
\hline Maximum power $($ at $3000 \mathrm{rpm}), \mathrm{kW}$ & $12.8 \pm 5 \%$ \\
\hline Injection pressure, bar & $175 \pm 5$ bar \\
\hline Specific fuel consumption, $\mathrm{g} \cdot(\mathrm{kWh})^{-1}$ & $255 \pm 5 \%$ \\
\hline Rated speed, rpm & 3000 \\
\hline Engine weight, $\mathrm{kg}$ & 135 \\
\hline
\end{tabular}

The subject of the research was diesel fuel, biodiesel, and biodiesel and n-butanol blend. Diesel fuel (class 2) was produced at the manufactory "Orlen Lietuva" and its quality parameters satisfied the requirements EN 590:2009 + A1. The RME was brought from the biofuel production company "Rapsoila" and its parameters satisfied the main requirements of the standard EN 14214:2009. The nbutanol $\left(\mathrm{CH}_{3} \mathrm{CH}_{2} \mathrm{CH}_{2} \mathrm{CH}_{2} \mathrm{OH}\right)$ was produced in Germany (Seelze) at Ltd. „Sigma-Aldrich” and satisfied the requirements of the specification 1.00988.6025 1-Butanol EMPROVE®ESSENTIAL NF.

Regardless that both biodiesel $(\mathrm{B})$ and $\mathrm{n}$-butanol $(\mathrm{Bu})$ are of the same renewable nature, nevertheless, the production of the tested biofuels derives from different resources by using different technologies, therefore, these biofuels differ as having completely different origins with widely differing chemical and physical properties (Table 2).

The torque of an engine was measured with a magnetic powder brake dynamometer PT40M (0$60 \mathrm{Nm})$ with a definition rate of $\pm 0.5 \mathrm{Nm}$ and the rotation speed with a mechanical tachometer (150$3000 \mathrm{rpm}$ ) with an accuracy of $\pm 0.5 \%$ of the measured value.

The air mass consumption was measured with a turbine type gas meter CGT-02 (10-100 $\left.\mathrm{m}^{3} \cdot \mathrm{h}^{-1}\right)$ with an accuracy of $\pm 1 \%$ of the measured value, and the fuel mass consumption by using electronic scale SK-1000 with an accuracy of $\pm 0.5 \%$.

Emissions of nitric oxide (NO), nitrogen dioxide $\left(\mathrm{NO}_{2}\right)$, carbon monoxide $(\mathrm{CO})$ in parts per million (ppm) and carbon dioxide $\left(\mathrm{CO}_{2}\right)$ in vol\% were measured with electrochemical cells installed in a Testo $350 \mathrm{XL}$ flue gas analyser. Total NOx emissions were determined as a sum of both $\mathrm{NO}$ and $\mathrm{NO}_{2}$ pollutants with an accuracy of $\pm 5 \mathrm{ppm}$. 
Properties of tested diesel fuel, rapeseed oil biodiesel, biodiesel and n-butanol blend

Table 2

\begin{tabular}{|l|l|c|c|c|}
\hline \multicolumn{1}{|c|}{ Property parameters } & Fuel test methods & $\begin{array}{c}\text { Diesel } \\
\text { fuel } \\
(\text { DD) }\end{array}$ & $\begin{array}{c}\text { Rapeseed oil } \\
\text { biodiesel (B) }\end{array}$ & $\begin{array}{c}\text { Biodiesel- } \\
\text { n-butanol } \\
\text { (BBu20) }\end{array}$ \\
\hline Density at $15^{\circ} \mathrm{C}, \mathrm{kg} \cdot \mathrm{m}^{-3}$ & EN ISO 12185:1999 & 831.7 & 884.7 & 806.2 \\
\hline $\begin{array}{l}\text { Kinematic viscosity, } \mathrm{mm}^{2} \cdot \mathrm{s}^{-1} \\
\text { at } 40^{\circ} \mathrm{C}\end{array}$ & $\begin{array}{l}\text { EN ISO } \\
\text { 3104 + AC:2000 }\end{array}$ & 2.22 & 4.60 & 3.63 \\
\hline Cetane number & EN ISO 5165:1999 & 51.4 & 53.1 & 47.7 \\
\hline Oxygen content, max wt\% & - & 0.40 & 10.90 & 13.04 \\
\hline Carbon-to-hydrogen ratio $(\mathrm{C} / \mathrm{h})$ & - & 6.50 & 6.49 & 6.15 \\
\hline $\begin{array}{l}\text { Stoichiometric air/fuel ratio, } \\
\mathrm{kg} \cdot \mathrm{kg}^{-1}\end{array}$ & - & 14.45 & 12.62 & 12.32 \\
\hline Net heating value, $\mathrm{MJ} \cdot \mathrm{kg}^{-1}$ & EN ISO 8217:2012 & 43.10 & 37.23 & 36.40 \\
\hline
\end{tabular}

Exhaust smoke was measured with a Bosch RTT 110 opacity meter with an accuracy of $\pm 0.1 \%$ in a scale range of $0-100 \%$. The measuring rages of apparatus used, accuracies of the measured experimental data of the engine performance and exhaust emission parameters, and the uncertainties of the calculated test results (power, fuel consumption etc.) are listed in Table 3.

Accuracy of the measured engine performance and emission

Table 3 parameters and uncertainty of computed experimental results

\begin{tabular}{|l|c|c|}
\hline \multicolumn{1}{|c|}{ Parameter } & Measuring range & Accuracy \\
\hline Torque & $0-60 \mathrm{Nm}$ & $\pm 1.5 \%$ \\
\hline Speed & $150-3000 \mathrm{rpm}$ & $\pm 0.5 \%$ \\
\hline $\mathrm{NO}$ & $0-3000 \mathrm{ppm}$ & $5 \%$ \\
\hline $\mathrm{NO}_{2}$ & $0-500 \mathrm{ppm}$ & $5 \%$ \\
\hline $\mathrm{CO}$ & $0-10000 \mathrm{ppm}$ & $5 \%$ \\
\hline $\mathrm{CO}_{2}$ & $0-50 \%$ & $1 \%$ \\
\hline Smoke density & $0-100 \%$ & $1.5 \%$ \\
\hline Engine power output & - & \pm 1 \\
\hline Fuel mass flow rate & - & \pm 0.5 \\
\hline Brake specific fuel consumption & - & \pm 1.5 \\
\hline Brake thermal efficiency & - & \pm 1.5 \\
\hline
\end{tabular}

To improve reliability of the measured data the tests have been repeated no less than three times.

\section{Results and discussion}

The dependence of fuel consumption per hour on the load, when the engine is running on different fuel compositions, is shown in Figure 1a. After analysing the obtained data, it was observed that in all load modes the lowest fuel consumption per hour was obtained, when the engine was running on diesel fuel, and the highest on biofuel BBu20 blend. This is influenced by the physical and chemical properties of the fuel.

The analysis of the graph $1 \mathrm{~b}$ shows that at low engine (10\%) load, the brake specific fuel consumption (bsfc) of the biofuel blend BBu20 is higher compared to on diesel and pure biodiesel running engine. Increasing the engine to average (50\%) load, the brake specific fuel consumption of the biofuel blend $\mathrm{BBu} 20$ increased by $20 \%$ compared to a diesel fuel running engine. Rising the engine load, the trends in biofuel consumption remained similar. Increasing the engine to full (100\%) load, the brake specific fuel consumption increased by augmenting the oxygen content of the fuel blends. The increased brake specific fuel consumption of the biofuel BBu20 blend can be explained by the lower calorific value of the biofuel.

With the engine running on the biofuel BBu20 blend, the brake specific fuel consumption increased by $24.1 \%$, and the brake thermal efficiency slightly decreased by $4.7 \%$ compared to a diesel fuel running engine (Fig. 2a). At low engine load, the brake thermal efficiency $\left(\eta_{e}\right)$ decreased by $2 \%$ using biofuel 
BBu 20 blends. At maximum engine load, the brake thermal efficiency $\left(\eta_{e}\right)$ reached its maximum value (0.282) with pure biodiesel fuel.
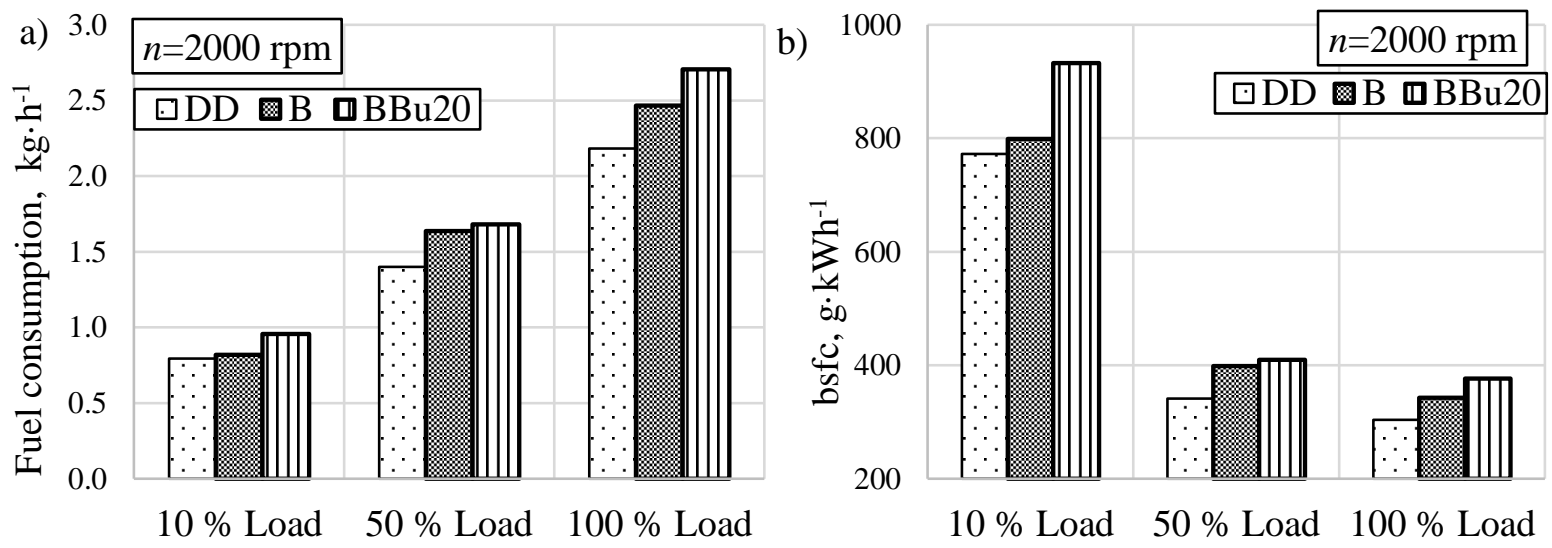

Fig. 1. Fuel consumption per hour and brake specific fuel consumption (bsfe) as a function of engine load at $2000 \mathrm{rpm}$

The total nitrogen oxide emissions ( $\mathrm{NOx}$ ) increased with increasing the engine load, gas pressure and the cylinder temperature. Traditional flue gas emission behaviour is fully in line with the prediction of the internal combustion engine theory (Heywood, 1988). The total NOx emissions sustain at a reasonable level, when running at the lowest (10\%) load varying within the narrow range from $321 \mathrm{ppm}$ for diesel to $489 \mathrm{ppm}$ for the biggest mass content of n-butanol containing biofuel BBu20 (Fig. 2b). The relatively higher NOx emissions emanating from the combustion reaction of the most n-butanol involving blend $\mathrm{BBu} 20$ can be reasonably attributed to the fact that the temperature inside the cylinder is too low to keep smooth operation of the engine on plenty n-butanol oxygenated biodiesel blend at the lowest load. Therefore, the increased combustion instability accompanied by the high noise levels and the in-cylinder pressure oscillations contributed to the production of more NOx emissions in these particular low-load conditions.
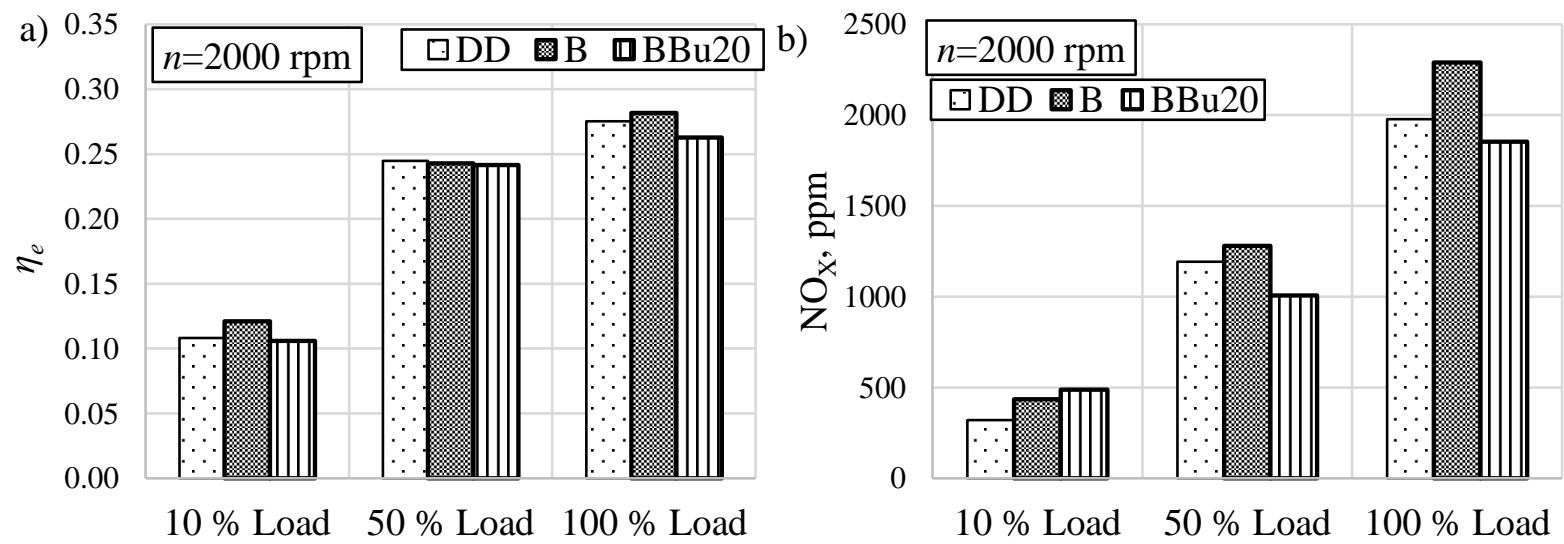

Fig. 2. Brake thermal efficiency $\left(\eta_{e}\right)$ and total nitrogen oxide $\left(\mathrm{NO}_{\mathrm{x}}\right)$ emissions as a function of engine load when running at maximum torque speed of $2000 \mathrm{rpm}$

The graph $2 \mathrm{~b}$ shows that the maximum NOx emission value of $2290 \mathrm{ppm}$ is obtained by running the engine on pure biodiesel. At average engine load, using biofuel blend BBu20, the total nitrogen oxide emissions decrease by $18.5 \%$ respectively. Increasing the engine load has a positive effect on the use of the biofuel blend BBu20 on NOx emissions. Lower NOx emissions are obtained, despite the higher oxygen content in the biofuel BBu20 blend, which often increases NOx emissions. At higher cylinder volumes, the pressure and temperature of the combustible gas are lower, resulting in lower emissions of nitrogen oxides. Increasing the engine to full load, nitrogen oxide emissions from the biofuel blend $\mathrm{BBu} 20$ were reduced by $6.6 \%$, compared to the engine running on the neat diesel fuel.

As it can be seen in graphs of Fig. 3a, at low engine load, the carbon monoxide (CO) emissions from biofuel blend BBu20 are higher than from pure diesel fuel. The increase in carbon monoxide emissions from the use of the $\mathrm{BBu} 20$ blend can be associated with a lower cetane number and a longer 
auto-ignition delay period. At average engine load using biofuel $\mathrm{BBu} 20$ blend, the $\mathrm{CO}$ emissions were reduced by $19.1 \%$, compared to the use of diesel fuel. As the engine load increased, the trend in CO emissions remained similar.

The amounts of carbon dioxide $\left(\mathrm{CO}_{2}\right)$ increased proportionally with increasing the load due to more fuel consumed to develop the required power output from the crankshaft. The biggest from 2.7 to $8.1 \mathrm{vol} \% \mathrm{CO}_{2}$ emissions were produced by a straight diesel within the tested load range. A bit lower from 2.7 to $7.8 \mathrm{vol} \%$ amounts of $\mathrm{CO}_{2}$ were generated the engine fuelled with neat biodiesel fuel. When using $\mathrm{BBu} 20$ fuel blend, $\mathrm{CO}_{2}$ emissions change negligibly compared to pure biodiesel fuel.
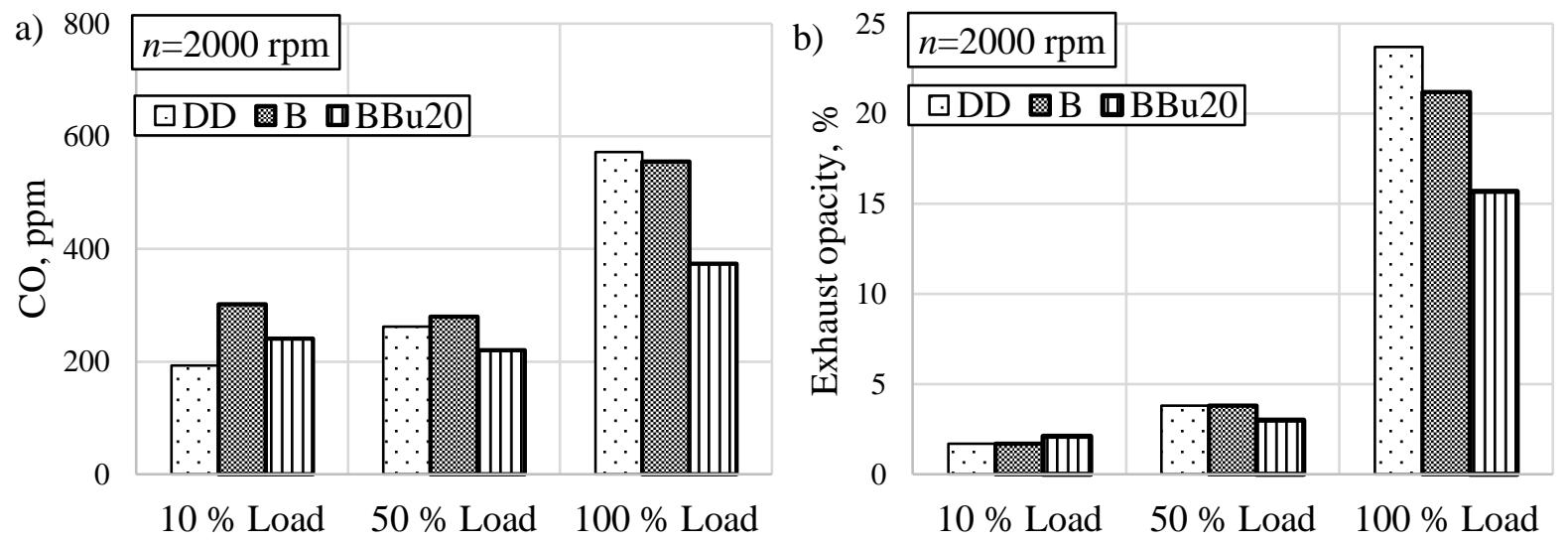

Fig. 3. Dependencies of carbon monoxide (CO) emissions and smoke opacity of exhaust on engine load when running at maximum torque speed of $2000 \mathrm{rpm}$

The smoke opacity of the exhaust from a diesel fuel and biofuel running engine is shown in Figure 3 b. Smoke of the exhaust was negligible, when running under light loads. The graphs show that the engine load had the greatest effect on the smoke opacity of the exhaust. With the engine running at medium load, the highest smoke opacity of the exhaust was generated by diesel fuel. When the engine was powered by an oxygen-saturated biofuel blend $\mathrm{BBu} 20$, at the average engine load, the smoke opacity of the exhaust was reduced by $26.6 \%$, compared to a diesel fuel working engine. When the load was increased to the maximum value, the oxygen-saturated biofuel Bu20 blend powered engine emitted $51 \%$ less smoke opacity of the exhaust, compared to the use of diesel fuel. Apart from the help of fuelbound oxygen in the combustion reactions to having lower smoke contributed all of them, lower density, $\mathrm{C} / \mathrm{h}$ atom ratio and stoichiometric air-fuel ratio of the tested fuel blends reduced the need for air-born oxygen on which transparency of the exhaust mainly depends.

\section{Conclusions}

1. The brake mean fuel consumption of biofuel and its blend over the entire range was higher. When $20 \mathrm{vol} \%$ (BBu 20) of n-butanol is added into the biodiesel fuel, the brake specific fuel consumption, increased by $20.7 \%-24.1 \%$, respectively, in comparison to diesel fuel.

2. In case of running the engine on biofuel blend $\mathrm{BBu} 20$ at rated $2000 \mathrm{~min}^{-1}$ speed and under full $(100 \%)$ load, the brake thermal efficiency was lower 0.263 (4.7\%) compared to normal diesel fuel 0.275 .

3. The highest total emissions (111 ppm) of nitrogen oxides NOx were measured from the engine running on biodiesel at the load of $100 \%$. When biofuel blend BBu20 was used, the total NOx emissions decreased by 23.5 compared to the biodiesel case.

4. When the engine is running on oxygenated biodiesel (B) and BBu20 blend, the carbon monoxide (CO) emissions decreased by $3.1 \%$ and $52.9 \%$, respectively, when running at medium (100\% of full) load.

5. The smoke opacity of the engine operating on biofuel (B) and BBu20 blend at medium engine load was reduced by 3.8 and 3.4, respectively, compared to the engine running on diesel fuel.

\section{References}

[1] Directive 2009/28/EC of the European Parliament and of the Council of 23 April 2009 on the promotion of the use of energy from renewable sources and amending and subsequently repealing 
Directives 2001/77/EC and 2003/30/EC. [online] [21.03.2021] Available at: https://eurlex.europa.eu/legal-content/EN/ALL/?uri=CELEX\%3A32009L0028

[2] Zheng J., Tashiro Y., Wang Q., Sonomoto K. REVIEW. Recent advances to improve fermentative butanol production: Genetic engineering and fermentation technology. Journal of Bioscience and Bioengineering, 2015, Vol. 119, Issue 1, pp. 1-9.

[3] Labeckas G., Slavinskas S., Rudnicki J., Zadrąg R. The effect of oxygenated diesel-n-butanol fuel blends on combustion, performance, and exhaust emissions of a turbocharged CRDI diesel engine. Polish Maritime Research, 2018, Vol. 25, No 1 (97), pp. 108-120, doi: 10.2478/pomr-2018-0013.

[4] Labeckas G., Slavinskas S., Kanapkienė I. Study of the effects of biofuel-oxygen of various origins on a CRDI diesel engine combustion and emissions. Energies, Based: MDPI AG, 2019, Vol. 12, Issue 7, pp. 1-49. [online] [21.03.2021] Available at: https:/ $\mathrm{h}^{-1} \mathrm{dl}$.handle.net/20.500.12259/61885.

[5] Rakopoulos D.C., Rakopoulos C.D., Giakoumis E.G. Impact of properties of vegetable oil, biodiesel, ethanol and n-butanol on the combustion and emissions of turbocharged HDDI diesel engine operating under steady and transient conditions. Fuel, 2015, Vol. 156, Issue 9 - September, p. 1-19, DOI: 10.1016/j.fuel.2015.04.021.

[6] Zöldy M. Fuel Properties of Butanol-Hydrogenated Vegetable Oil Blends as a Diesel Extender Option for Internal Combustion Engines. Periodica Polytechnica Chemical Engineering, 2020, Vol. 64, Issue 2, pp. 205-212. DOI: 10.3311/PPch.14153.

[7] Lapuerta M., Hernandez J.J., Fernandez-Rodríguez D., Cova-Bonillo A. Autoignition of blends of n-butanol and ethanol with diesel or biodiesel fuels in a constant-volume combustion chamber. Energy, 2016, Vol. 118, p. 613-621.

[8] Sukjit E., Herreros J.M., Dearn K.D., Tsolakis A., Theinnoi K. Effect of hydrogen on butanolbiodiesel blends in compression ignition engines. International Journal of Hydrogen Energy, 201302-06, Vol. 38, Issue 3, p. 1624-1635. doi: 10.1016/j.ijhydene.2012.11.061.

[9] Wei L., Cheung C.S., Ning Z. Effects of biodiesel-ethanol and biodiesel-butanol blends on the combustion, performance and emissions of a diesel engine. Energy, 2018-07-15, Vol. 155, Issue 3, pp. 957-970, DOI: 10.1016/j.energy.2018.05.049. 